\title{
No smoke without fire: The impact of future friends on adolescent smoking behaviour
}

Citation for published version (APA):

Mercken, L., Candel, M., van Osch, L., \& de Vries, H. (2011). No smoke without fire: The impact of future friends on adolescent smoking behaviour. British Journal of Health Psychology, 16, 170-188.

https://doi.org/10.1348/135910710X531608

Document status and date:

Published: 01/02/2011

DOI:

10.1348/135910710X531608

Document Version:

Publisher's PDF, also known as Version of record

Document license:

Taverne

Please check the document version of this publication:

- A submitted manuscript is the version of the article upon submission and before peer-review. There can be important differences between the submitted version and the official published version of record.

People interested in the research are advised to contact the author for the final version of the publication, or visit the DOI to the publisher's website.

- The final author version and the galley proof are versions of the publication after peer review.

- The final published version features the final layout of the paper including the volume, issue and page numbers.

Link to publication

\footnotetext{
General rights rights.

- You may freely distribute the URL identifying the publication in the public portal. please follow below link for the End User Agreement:

www.umlib.nl/taverne-license

Take down policy

If you believe that this document breaches copyright please contact us at:

repository@maastrichtuniversity.nl

providing details and we will investigate your claim.
}

Copyright and moral rights for the publications made accessible in the public portal are retained by the authors and/or other copyright owners and it is a condition of accessing publications that users recognise and abide by the legal requirements associated with these

- Users may download and print one copy of any publication from the public portal for the purpose of private study or research.

- You may not further distribute the material or use it for any profit-making activity or commercial gain

If the publication is distributed under the terms of Article $25 \mathrm{fa}$ of the Dutch Copyright Act, indicated by the "Taverne" license above, 


\title{
No smoke without fire: The impact of future friends on adolescent smoking behaviour
}

\author{
L. Mercken I,2*, M. Candel ${ }^{1,3}$, L. van Osch ${ }^{1,2}$ and H. de Vries ${ }^{1,2}$ \\ 'Care and Public Health Research Institute (CAPHRI), Maastricht, The Netherlands \\ ${ }^{2}$ Department of Health Promotion, Maastricht University, The Netherlands \\ ${ }^{3}$ Department of Methodology and Statistics, Maastricht University, The Netherlands
}

\begin{abstract}
Objective. This study examined the impact of future friends and the contribution of different social influence and selection processes in predicting adolescents' smoking behaviour by extending the theory of planned behaviour (TPB). We investigated the impact of previous smoking, direct pressure from friends, descriptive norms of present and future friends, smoking-based selection of future friends, and distinguished between reciprocal and desired friends.
\end{abstract}

Design. A longitudinal design with three measurements was used.

Methods. The sample consisted of I,475 Dutch high school students (mean age $=12.7$ years) that participated as a control group in the European Smoking prevention Framework Approach study at three measurements.

Results. Structural equation modelling revealed that adolescent smoking was influenced by intention, previous smoking, descriptive norms of parents and siblings, and that desired as well as reciprocal friends were selected based on similar smoking behaviour. Future friends indirectly influenced adolescent smoking through intention, as did attitude, subjective norms of parents and siblings, previous smoking, and descriptive norms of reciprocal friends and siblings.

Conclusions. The present results suggest that descriptive norms and selection of friends need to be considered as major factors explaining smoking behaviour among adolescents besides the TPB components. These insights contribute to the further refinement of smoking prevention strategies.

Cigarette smoking is one of the main causes of cancer, heart disease, and premature death in many countries (Ezzati \& Lopez, 2003; Office for National Statistics, 1997; Warren, Jones, Eriksen, \& Asma, 2006). During adolescence, many youngsters experiment with smoking which may result in becoming a regular smoker (Chassin, Presson, Rose, \& Sherman, 1996). Hence, it is important to understand which factors contribute to smoking behaviour during adolescence. The main aim of this study is to examine the specific role of adolescents' future friends in predicting adolescents' smoking behaviour

\footnotetext{
*Correspondence should be addressed to Dr L. Mercken, Department of Health Promotion, Maastricht University, PO Box 616, 6200 MD Maastricht, The Netherlands (e-mail: liesbeth.mercken@maastrichtuniversity.nl).
} 
and to analyse the contribution of different social influence and selection processes by extending the theory of planned behaviour (TPB; Ajzen, 1991).

Future friends are those peers that are going to be chosen as friends in the near future and might already influence adolescent smoking before the friendship is formed. If a longitudinal association exists between the smoking behaviour of future friends and adolescents, this can imply that adolescents adjusted their smoking behaviour to the smoking behaviour of their future friends. It is also feasible that adolescents are not influenced by the smoking behaviour of these friends, but select future friends based on similar smoking behaviour. Recent longitudinal social network studies found evidence that adolescents selected new friends based on similarities in their smoking rates (Mercken, Snijders, Steglich, \& De Vries, 2009; Mercken, Snijders, Steglich, Vartiainen, $\&$ de Vries, 2010). Although advanced social network analysis techniques were used to validly disentangle selection and influence processes, these studies did not reveal the influence that can still take place before friends are selected. No study examined yet the effect of selection and influence of future friends on adolescent smoking within the context of TPB.

The TPB (Ajzen, 1991) is an influential theory for the prediction of behaviour. It is an extended version of the theory of reasoned action (Ajzen \& Fishbein, 1980) and encompasses social influences and personal factors as predictors of behaviour. In terms of adolescent smoking, TPB postulates that smoking-related cognitions, that is, attitude, subjective norms, and perceived behavioural control (PBC), predict adolescents' intention to smoke, and intention in its turn, predicts smoking behaviour (Ajzen, 1991). Attitude can be defined as the beliefs people have about the likely outcomes of the behaviour and the evaluations of these outcomes. Subjective norms are a person's conceptualization of what significant others think the person ought to do. PBC is defined as a person's own perception of how easy or difficult it is to execute a certain behaviour, and will predict actual behaviour also directly when it provides an accurate picture of actual control (Ajzen, 1991). Various studies have supported the predictive validity of the TPB regarding smoking (De Vries, Backbier, Kok, \& Dijkstra, 1995; De Vries, Dijkstra, \& Kuhlman, 1988; Godin, Valois, Lepage, \& Desharnais, 1992; Guo et al., 2007; Hill, Boudreau, Amyot, Déry, \& Godin, 1997; Smith, Bean, Mitchell, Speizer, \& Fries, 2007).

Subjective norms generally show a significant weaker association with intention than attitude and PBC (Armitage \& Conner, 2001). Although this might imply that intentions are mainly affected by personal factors (Ajzen, 1991), evidence suggests that the conceptualization of subjective norms might be too narrow (Armitage \& Conner, 2001; Rivis \& Sheeran, 2003; Sheeran \& Orbell, 1999). Subjective norms as defined by the TPB are concerned solely with a person's conceptualization of what significant others think the person ought to do. However, adolescents might also act upon the actual behaviour of others. For instance, the process of modelling, resulting in vicarious learning of the advantages of a particular behaviour, is described in Bandura's (1977) social cognitive theory. The impact of modelling has been previously examined (Avenevoli \& Merikangas, 2003), and recognized in extended TPB models as descriptive norms (Ajzen, 2002a; De Vries et al., 1995; Grube, Morgan, \& McGree, 1986; Hoving, Reubsaet, \& De Vries, 2007; McMillan, Higgins, \& Conner, 2005). Adolescents' smoking has been shown to be influenced by descriptive norms of parents (Bricker, Peterson, Anderson, et al., 2006; Conrad, Flay, \& Hill, 1992), siblings (Bricker, Peterson, Anderson, et al., 2006; Bricker, Peterson, Leroux, et al., 2006; Harakeh, Engels, Vermulst, De Vries, \& Scholte, 2007), and friends (Bricker, Peterson, Anderson, et al., 2006; De Vries, Engels, Kremers, Wetzels, \& Mudde, 2003; West, Sweeting, \& Ecob, 1999). 
Adolescents might also experience direct pressure to smoke besides being indirectly influenced to smoke by observing family, friends, and future friends. Direct pressure encompasses behaviours like offering a cigarette, persuasion, challenging, or pestering someone to smoke (De Vries et al., 1995). Several studies reported significant effects of direct pressure from friends (De Vries et al., 1995; Evans, 1976; Hoving et al., 2007; McAlister, Perry, \& Maccoby, 1979), even in the context of smoking-related cognitions (De Vries et al., 1995; Hoving et al., 2007). Consequently, direct as well as indirect influences should be considered when predicting smoking behaviour.

Besides examining the specific role of future friends, three additional issues have been overlooked in many studies extending the TPB. First, when analysing the impact of subjective and descriptive norms many studies do not consider different social agents. Parental norms might differ from norms of friends or siblings (Grube et al., 1986). Second, the impact of reciprocity in friendships has not been considered. Although support for influence of desired (non-reciprocal) friends has been reported previously (Aloise-Young, Graham, \& Hansen, 1994; Mercken, Candel, Willems, \& De Vries, 2009), a number of studies have demonstrated that reciprocal friends might exert a stronger influence on smoking behaviour than desired friends (Parker \& Asher, 1993; Urberg, Luo, Pilgrim, \& Degirmencioglu, 2003). Although these studies did not consider TPB components, their results stress the importance of friendship reciprocity. Finally, often data are gathered in two waves to assess smoking-related cognitions and behaviour (Grube et al., 1986; Hoving et al., 2007; McMillan et al., 2005). With data gathered in three successive waves, and attitudes, subjective norms, and PBC assessed at the first (T1), intention at the second (T2), and smoking behaviour at the third measurement (T3), the causality of the TPB model can be tested more accurately.

The main goal of this study is to examine the impact of future friends and to analyse the contribution of different social influence and selection processes in predicting adolescents' future smoking behaviour by extending the TPB and taking all issues mentioned into account. The possible indirect impact of the extension variables through adolescents' intention to smoke will also be modelled. Age, gender, ethnicity, and alcohol consumption will be included as covariates in our analyses as they are known to possibly affect smoking behaviour (Bergen \& Caporaso, 1999; Mercken, Candel, Willems, \& De Vries, 2007; Mermelstein, 1999). Figure 1 shows the extended TPB model. Our main hypotheses are:

H1: Attitude, subjective norms, and PBC are expected to predict smoking intentions, while intentions and $\mathrm{PBC}$ are expected to predict subsequent smoking behaviour.

H2: Adolescents select future friends based on similar smoking behaviour.

H3: Descriptive norms of future friends affect adolescent smoking: the more friends smoke, the more adolescents smoke.

H4: Descriptive norms of present friends affect adolescent smoking: the more friends smoke, the more adolescents smoke.

H5: Direct pressure from friends leads to increased adolescent smoking.

H6: Descriptive norms of parents and siblings influence adolescent smoking: the more parents and siblings smoke, the more adolescents smoke.

H7: Previous smoking behaviour will predict future smoking behaviour. 


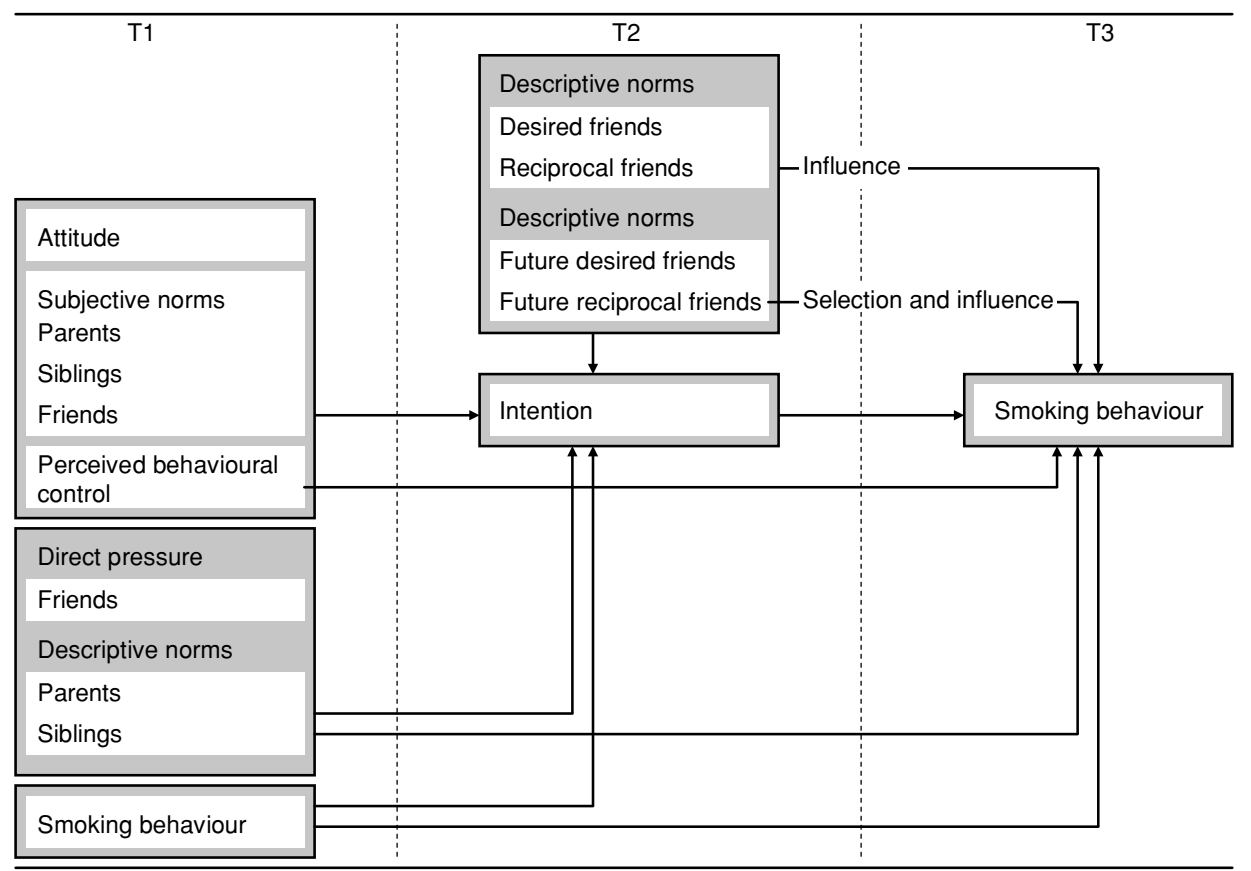

Figure I. The extended TPB applied to adolescent smoking behaviour. TI, measurement I; T2, measurement 2; T3, measurement 3.

\section{Methods}

\section{Participants}

The sample consisted of 1,886 adolescents that participated as a control group in the European Smoking prevention Framework Approach (ESFA) study in The Netherlands (De Vries et al., 2003). The ESFA study was a smoking prevention project in six European countries, featuring activities for adolescents, schools, and parents, including out-ofschool activities. Only adolescents of the control group were included, since the smoking prevention intervention was effective (De Vries et al., 2006), and relationships between variables of interest might have changed.

Of all 1,886 participants, 50\% were girls, $76.1 \%$ were native Dutch, $5.2 \%$ were Mediterranean, $5.2 \%$ had a mixed background, and $4.7 \%$ indicated to have another ethnic background. At baseline, the adolescents' mean age was 12.7 years $(S D=0.61)$. Assessment of the respondents' smoking behaviour showed that $91.5 \%$ of the adolescents were non-smokers, $3.9 \%$ smoked 0 to 1 cigarette a week, $2.6 \%$ from 2 to 10 cigarettes, $1 \%$ from 11 to 30 , and $0.7 \%$ smoked more than 30 cigarettes a week. Although figures differ slightly because of sampling and differences in questionnaires, they are to a large extent comparable to those found in an earlier study (Currie et al., 2004).

\section{Attrition analyses}

At baseline, 1,886 adolescents completed the questionnaire. Out of these, 1,475 completed the questionnaire at $\mathrm{T} 2$ as well as $\mathrm{T} 3(78.2 \%)$. Response at $\mathrm{T} 3$ was significantly predicted by gender $(\mathrm{OR}=0.56 ; 95 \% \mathrm{CI}[0.40,0.80] ; p<.01)$, intention $(\mathrm{OR}=1.16$; $95 \%$ CI $[1.09,1.23] ; p<.01)$, and subjective norm of parents $(\mathrm{OR}=0.85 ; 95 \% \mathrm{CI}[0.76$, 
$0.95] ; p<.05)$. Females, respondents with a higher intention to smoke, and respondents whose parents had pro-smoking norms were less likely to respond.

\section{Procedure}

Self-administered questionnaires were distributed among seventh graders of each participating school during the autumn of 1998 (T1). Follow-up was conducted 12 (T2) and 24 (T3) months later (De Vries et al., 2003). Students present on the day of data collection were explained that responses would be treated confidentially and that they could refuse to participate. Students returned their questionnaires in sealed envelopes to guarantee confidentiality. At baseline, the proportion of refusals was .56\% (De Vries et al., 2003).

\section{Questionnaire}

The ESFA questionnaire was based on earlier studies about adolescent smoking behaviour (De Vries et al., 2003; Dijkstra, Mesters, De Vries, van Breukelen, \& Parcel, 1999; Kremers, Mudde, \& De Vries, 2001a, b; Lawrance, 1989).

Attitude was assessed with 12 smoking-related beliefs such as 'If I smoke (or were to smoke): it will make me feel very relaxed (3)/ very stressed (-3), it tastes really nice (3)/ really horrible (-3), I seem much more confident in company (3)/ much less confident (-3)' (Cronbach's $\alpha=.74)$.

$P B C$ was measured with 12 items such as 'Do you think you are able not to smoke: when you are with friends who smoke?, when you are offered a cigarette?, when you are on the way home from school' $(-3=$ I am sure I will smoke, $3=$ I am sure I won't smoke) $(\alpha=.95)$.

Subjective norm of friends was measured with two questions asking respondents what their friends and best friend would expect them to do $(-3=$ I definitely should not smoke, $3=$ I definitely should smoke $)(\alpha=.85)$.

Subjective norm of parents was assessed by asking respondents what their mother (female caregiver) and father (male caregiver) would expect them to do. By averaging, answers were recoded into one variable $(-3=\mathrm{I}$ definitely should not smoke, $3=\mathrm{I}$ definitely should smoke).

Subjective norm of siblings was assessed by asking respondents what their brother(s) and sister(s) would expect them to do. Answers were averaged ( $-3=$ I definitely should not smoke, 3 = I definitely should smoke).

Intention was measured with two questions: 'Do you intend to smoke in the future?' and 'Do you intend to smoke in the next year?' $(-3=$ definitely not, $3=$ definitely) $(\alpha=.91)$.

Direct pressure from friends was measured with two questions asking respondents whether they ever felt pressure to smoke from their friends and best friend. By averaging answers were recoded into one variable $(0=$ never, $4=$ very often $)(\alpha=.74)$.

Respondents' smoking behaviour was assessed at T1 and T3 with one question: 'On average, how many cigarettes do you smoke during a week (including the weekend)?' $(0=0,1=$ between 0 and $1,2=1-10,3=11-30,4 \geq 30)$.

Descriptive norms of reciprocal and desired (non-reciprocal) best friends were assessed primarily by means of a name generator in which respondents could name up to five 'best friends' (McCallister \& Fisher, 1978). Of these nominated friends, only friends in the same grade inside school were included, as only they also filled out the 
questionnaire at exactly the same time. The self-reported smoking behaviour of each nominated friend at $\mathrm{T} 2$ was traced back in their personal questionnaire of that same year. In view of the ordinal nature of the respondent's smoking behaviour variable, median scores of the smoking behaviour of respondents' reciprocal and desired best friends were calculated. Reciprocal friends perceive the respondent to be their friend as well, whereas desired friends do not perceive the respondent to be their friend.

Descriptive norms of future reciprocal and desired best friends were assessed by the same name generator. Future best friends encompass only friends that were nominated for the first time at T3. The self-reported smoking behaviour of these friends was traced back in their personal questionnaire at T2 when the friendship was not yet established. Median scores of the smoking behaviour of each respondent's future reciprocal and desired friends were calculated.

Descriptive norms of parents was measured by two questions: 'Does your father (or male caregiver) smoke?' and 'Does your mother (or female caregiver) smoke?'. The answers were recoded into one variable $(0=$ neither of my parents (or caregivers) smoke, 1 = at least one of my parents (or caregivers) smokes).

Descriptive norms of siblings was measured by two questions: 'Do one or more of your brother(s) smoke?' and 'Do one or more of your sister(s) smoke?', and was recoded into one variable $(0=$ neither of my siblings smoke, $1=$ at least one of my siblings smokes).

We also recorded the respondent's age (years), gender $(0=$ boy, $1=$ girl $)$, ethnicity $(0=$ non-native, $1=$ native $)$, and alcohol consumption $(0=0$ glasses of alcoholic drinks per week, $1=1-2$ glasses, $2=3-5$ glasses, $3 \geq 5$ glasses; 1 glass $=10 \mathrm{~g}$ of pure alcohol), which served as covariates in the analysis.

\section{Analyses}

To examine the role of influence and selection processes in the prediction of smoking behaviour, structural equation models were tested employing Mplus 4.1 (Muthén \& Muthén, 2004). Since some variables were not normally distributed, a robust maximumlikelihood analysis was performed (Bentler \& Yuan, 1999). First, a model representing the TPB (Ajzen, 1991) will be tested. Subsequently, the TPB model will be extended with each of the proposed constructs separately to identify the unique contribution of each of the proposed constructs to the TPB. Finally, an integrated model, combining all proposed constructs will be analysed.

Additional analyses will be performed on two subsamples to disentangle selection and influence processes. For adolescents whose smoking behaviour did not change between T2 and T3, pathways from descriptive norms of future friends towards adolescent smoking at T3 are likely to represent selection based on similar smoking behaviour. For adolescents whose smoking behaviour changed, these pathways likely reflect influence of future friends.

\section{Results}

\section{Descriptives}

Table 1 displays the smoking behaviour of adolescents, friends, parents, and siblings for those adolescents that were included in the analyses and participated at all three measurements $(N=1,475)$. Respondents nominated 5,671 best friends at T2 out of which 3,289 were in the same school and grade as the respondents. Out of these, $50.6 \%$ 
Table I. Percentages of adolescents, friends, parents, and siblings in each smoking behaviour category

\begin{tabular}{lcrccc}
\hline & \multicolumn{5}{c}{ Smoking behaviour $(N=1,475)$} \\
\cline { 2 - 6 } & 0 & 1 & 2 & 3 & 4 \\
\hline T1 smoking behaviour adolescents & 93.14 & 3.19 & 2.45 & 0.54 & 0.68 \\
T1 smoking behaviour parents & 50.78 & 49.22 & - & - & - \\
T1 smoking behaviour siblings & 87.78 & 12.22 & - & - & - \\
T2 smoking behaviour desired friends & 85.75 & 5.60 & 5.09 & 1.78 & 1.78 \\
T2 smoking behaviour reciprocal friends & 91.35 & 3.48 & 3.35 & 0.65 & 1.16 \\
T2 smoking behaviour future desired friends & 72.09 & 4.94 & 7.04 & 6.47 & 9.47 \\
T2 smoking behaviour future reciprocal friends & 77.34 & 6.10 & 6.21 & 4.14 & 6.21 \\
T3 smoking behaviour adolescents & 77.16 & 5.78 & 5.78 & 3.97 & 7.31 \\
\hline
\end{tabular}

Note. $N$, number of included cases. Smoking behaviour adolescents and friends: $0=0$ cigarettes during a week; I = between 0 and I; $2=1-10 ; 3=11-30 ; 4 \geq 30$. Smoking behaviour parents and siblings: $0=$ none of them smokes; $\mathrm{I}=$ at least one of them smokes.

were reciprocal friends. Between T2 and T3, respondents selected 2,154 new friends within the same school and grade. Out of these, $42.6 \%$ were future reciprocal friends.

Table 2 shows that all included predictors were correlated with adolescent smoking behaviour. The smoking-related cognitions were associated stronger with intention than with adolescent smoking. Subjective norms of parents, siblings, and friends showed weaker associations with intention than attitude and PBC.

\section{Model results}

Table 3 depicts the results of the TPB model and the extended TPB models. Adolescents with a high intention to smoke (T2) and low PBC (T1) were more likely to smoke at a higher rate (T3). Intention and PBC explained nearly $28 \%$ of the variance in smoking behaviour. Adolescents with a positive attitude towards smoking (T1), low PBC (T1), and perceiving a pro-smoking subjective norm of siblings (T1) had a higher intention to smoke one year later (T2). The TPB components explained $14 \%$ of the variance in adolescents' intentions to smoke. Direct pressure (T1) and smoking behaviour of friends (T2) added the least to the variance explained of adolescents' intention to smoke (T2) and actual smoking behaviour (T3), whereas smoking behaviour of future friends (T2) was most powerful in improving the explained variance of adolescents' intentions (T2) and smoking behaviour (T3).

Table 4 shows the results of the integrated model. In line with the results of the TPB model (H1), adolescents' smoking behaviour was significantly predicted by intention to smoke. Adolescents' intention was significantly predicted by attitude and subjective norms of siblings and parents. However, the direct and indirect effects of PBC on smoking were not significant anymore. Except for direct pressure of friends and descriptive norms of desired friends, all extension variables significantly affected adolescent smoking behaviour and/or adolescent's intention to smoke, after controlling for the impact of the TPB components. The extension variables together added $15 \%$ to the explained variance of adolescent smoking behaviour. The explained variance of adolescents' intention increased with 13\% after extending the TPB model. None of the covariates significantly related to adolescent smoking behaviour directly. However, 


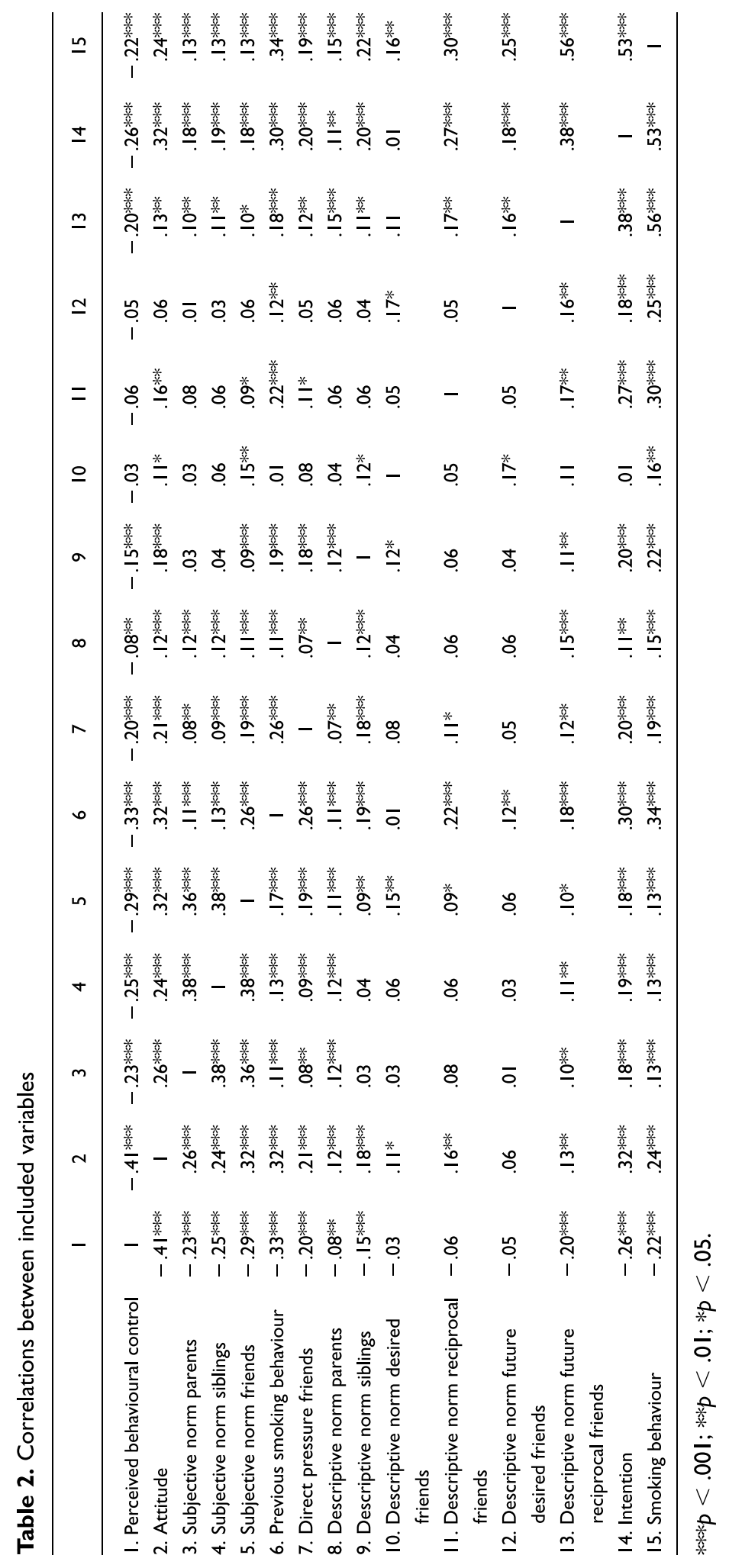




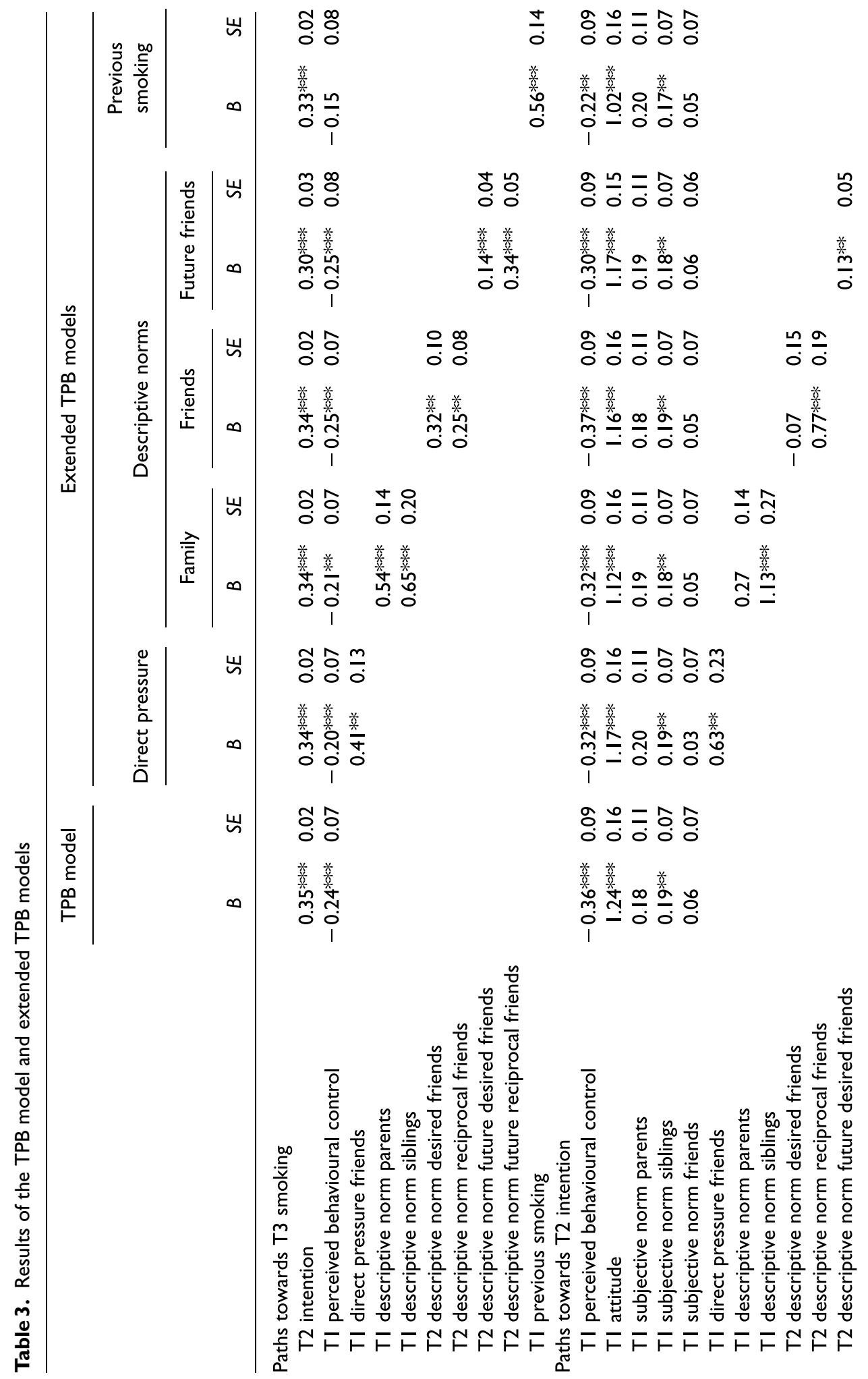




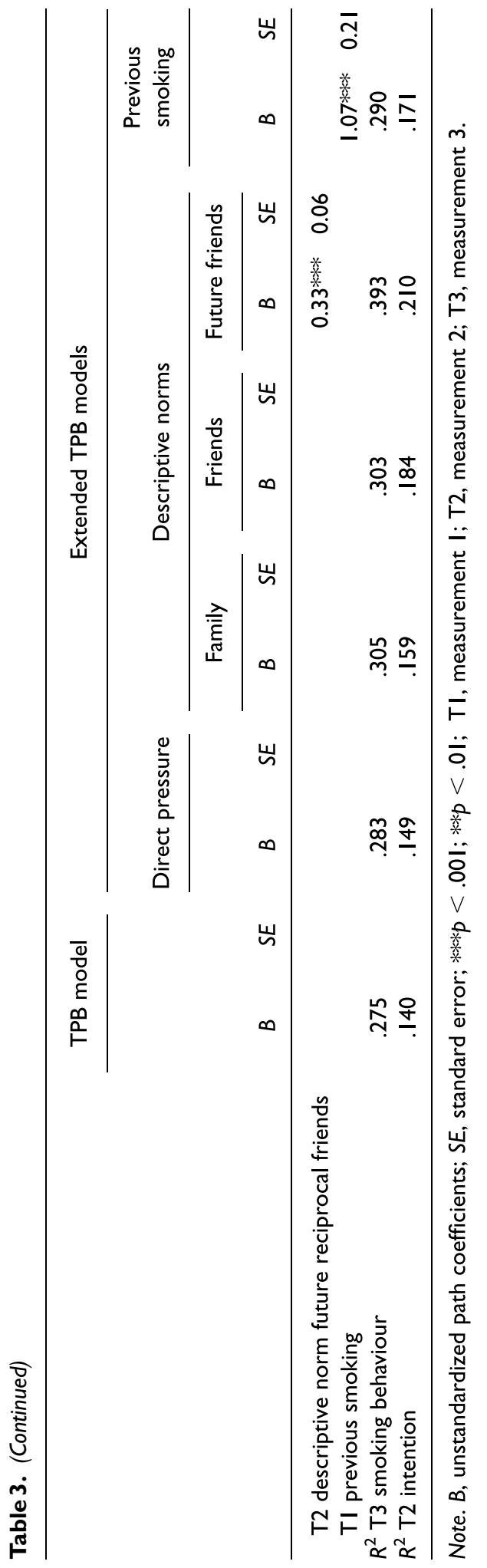


Table 4. Results from the integrated model

\begin{tabular}{lll}
\hline Paths towards smoking behaviour and intention & $B$ & $S E$ \\
\hline T3 smoking behaviour & & \\
T2 intention & $0.27^{* * *}$ & 0.03 \\
TI perceived behavioural control & 0.10 & 0.09 \\
TI direct pressure friends & 0.31 & 0.16 \\
TI descriptive norm parents & $0.49^{* * *}$ & 0.16 \\
TI descriptive norm siblings & $0.63^{* *}$ & 0.22 \\
T2 descriptive norm desired friends & 0.21 & 0.11 \\
T2 descriptive norm reciprocal friends & 0.18 & 0.16 \\
T2 descriptive norm future desired friends & $0.14^{* * *}$ & 0.04 \\
T2 descriptive norm future reciprocal friends & $0.34^{* * *}$ & 0.05 \\
T1 previous smoking behaviour & $0.55^{* * *}$ & 0.14 \\
T2 intention & & \\
TI perceived behavioural control & -0.17 & 0.09 \\
T1 attitude & $0.86^{* * *}$ & 0.15 \\
T1 subjective norm parents & $0.21^{*}$ & 0.11 \\
T1 subjective norm siblings & $0.17^{* *}$ & 0.07 \\
T1 subjective norm friends & 0.02 & 0.06 \\
TI direct pressure friends & 0.30 & 0.22 \\
TI descriptive norm parents & 0.12 & 0.13 \\
TI descriptive norm siblings & $0.92^{* * *}$ & 0.26 \\
T2 descriptive norm desired friends & -0.22 & 0.15 \\
T2 descriptive norm reciprocal friends & $0.56^{* * *}$ & 0.16 \\
T2 descriptive norm future desired friends & $0.13^{* *}$ & 0.05 \\
T2 descriptive norm future reciprocal friends & $0.28^{* * *}$ & 0.06 \\
T1 previous smoking behaviour & $0.77^{* * *}$ & 0.22 \\
$R^{2}$ T3 smoking behaviour & 0.43 & \\
$R^{2}$ T2 intention & 0.27 & \\
\hline
\end{tabular}

Note. $B$, unstandardized path coefficient; $S E$, standard error; TI, measurement I; T2, measurement 2; T3, measurement 3; ***p $<.001 ; * * p<.01 ; * p<.05$.

adolescent's intention to smoke was significantly predicted by gender. Girls had a higher intention to smoke compared to boys (unstandardized coefficient $=0.53 ; p<.001$ ).

Descriptive norms of future friends $(\mathrm{H} 3)$

Smoking behaviour of future desired and reciprocal friends was highly significant in the prediction of adolescents' smoking behaviour and intention to smoke. Adolescents with smoking future friends smoked more and showed a higher intention to smoke.

Descriptive norms of present friends $(\mathrm{H} 4)$

Adolescents' smoking behaviour was not significantly influenced directly by the smoking behaviour of their desired and reciprocal friends. However, a trend was visible indicating that adolescents smoked more cigarettes when their desired friends smoked at a higher rate. Smoking of reciprocal friends influenced adolescents' smoking only indirectly through adolescents' intention to smoke. Adolescents with smoking reciprocal friends had a higher intention to smoke. 
Direct pressure from friends $(\mathrm{H} 5)$

No significant effect was found from direct pressure on adolescent's actual smoking behaviour. However, the results did show a trend indicating that adolescents perceiving more pressure from their friends, smoked at a higher rate. Adolescents' intention to smoke was not significantly predicted by direct pressure from friends.

Descriptive norms of parents and siblings $(\mathrm{H} 6)$

Adolescents smoked at a higher rate when at least one of their parents smoked. Parental smoking did not significantly predict adolescents' intention to smoke. Adolescents with smoking siblings were more likely to smoke at a higher rate and to have a higher intention to smoke.

Previous smoking behaviour (H7)

Adolescents' smoking behaviour and intentions to smoke were significantly predicted by previous smoking behaviour.

Additional analyses for future friends $(\mathrm{H} 2-\mathrm{H} 3)$

To examine whether the paths from descriptive norms of future friends towards adolescent smoking represent selection and/or influence processes, additional analyses were performed on two subsamples. The first subsample included adolescents that nominated a future friend and whose smoking behaviour changed between T2 and T3 (influence; $n=234$ ). The second subsample included adolescents whose smoking behaviour did not change between T2 and T3 (selection; $n=785$ ). Results are reported in Table 5. Adolescents were not influenced by their future friends but seemed to select future desired as well as reciprocal friends based on similar smoking behaviour.

Table 5. Selection and influence of future friends

B

SE

Selection of future friends $(n=785)$

T3 smoking behaviour on

$\begin{array}{lll}\text { T2 descriptive norm future desired friends } & 0.21 * & 0.09\end{array}$

$\begin{array}{lll}\text { T2 descriptive norm future reciprocal friends } & 0.37^{* *} & 0.16\end{array}$

Influence of future friends $(n=234)$

T3 smoking behaviour on

T2 descriptive norm future desired friends $\quad 0.07$

$\begin{array}{lll}\text { T2 descriptive norm future reciprocal friends } & 0.30 & 0.17\end{array}$

Note. B, unstandardized path coefficient; SE, standard error; TI, measurement I; T2, measurement 2; T3, measurement 3; **p $<.01 ; * p<.05$.

\section{Discussion}

This study examined the impact of future friends and analysed the contribution of different social influence and selection processes in predicting adolescents' future 
smoking behaviour by extending the TPB. The results of this study are to a large extent in agreement with the TPB (Ajzen, 1991). Smoking-related cognitions indirectly affected adolescents' smoking behaviour through the intention to smoke. Attitude, subjective norms of siblings and parents, and perceived behaviour control predicted adolescents' smoking behaviour indirectly though intentions to smoke. Perceived behaviour control furthermore predicted smoking behaviour directly besides adolescents' intentions to smoke. The effects of perceived behaviour control, however, diminished when the extension variables were added to the model.

Descriptive norms of future friends were strongly associated with adolescents' smoking directly and indirectly through adolescents' intention. In line with Hypothesis 2 and previous research reporting selection processes to be an important factor in explaining adolescent smoking (Cohen, 1977; Engels, Knibbe, Drop, \& de Haan, 1997; Ennett \& Bauman, 1994; Fisher \& Bauman, 1988; Mercken, Candel, et al., 2009; Mercken, Snijders, et al., 2009; West et al., 1999), adolescents seemed to select reciprocal as well as desired friends based on similar smoking behaviour. Furthermore, adolescents seemed not to be influenced by these future friends to change their smoking behaviour. However, a possibility remains that adolescents were influenced not to change but to hold on to their present smoking behaviour. Future research should consider this possibility when examining influence and selection processes.

Descriptive norms of desired friends did not significantly affect adolescent smoking behaviour, although a clear trend was visible which is in line with previous research (Aloise-Young et al., 1994; Mercken, Candel, et al., 2009). Descriptive norms of reciprocal friends were significantly associated with adolescents' intention to smoke but did not directly affect actual smoking. The lack of strong support for the direct effects of reciprocal and desired friends' smoking behaviour on adolescent smoking behaviour contrasts with previous research in which descriptive norms of friends did significantly predict adolescent smoking behaviour (Grube et al., 1986; Simons-Morton \& Chen, 2006). These differences might be due to the lack of control for TPB components in these studies, or the use of smoking behaviour as reported by the friends themselves, which possibly led to avoiding projection bias in the present study (Bauman \& Ennett, 1996; Bauman \& Fisher, 1986; Kobus, 2003). On the other hand, the use of actual smoking behaviour in this study prevented large age differences between the adolescents and their friends, since only data of friends in the same grade inside school could be used. It might be that adolescent smoking is more strongly influenced by smoking behaviour of older-aged children (Bricker, Anderson, Rajan, Sarason, \& Peterson, 2007).

When extending the TPB, significant support was found for direct pressure from friends which is in line with previous studies (De Vries et al., 1995; Evans, 1976; Hoving et al., 2007). However, when all extension variables were included in the model, the direct and indirect impact of friends' pressure on smoking behaviour largely diminished. Only a trend, indicating that adolescents' actual smoking behaviour was influenced by direct pressure from their friends remained.

In line with our sixth hypothesis, descriptive norms of parents and siblings were directly related to adolescent smoking. The influence of siblings seems slightly stronger than the influence of parents, and contrary to parental smoking, sibling smoking also indirectly affected adolescent smoking through intention. These findings concur with previous research (Avenevoli \& Merikangas, 2003; Bricker, Peterson, Leroux, et al., 2006; McMillan et al., 2005; Rivis \& Sheeran, 2003). The significant association between descriptive norms of parents and adolescent smoking, however, is in contrast with the results of a previous study on similar data (Mercken et al., 2007). These differences might 
be due to the elapsed time between two successive measurements. In the present study, we used a 2-year time interval for examining modelling effects while the previous study used a 1-year time interval. One explanation is that adolescents learn to remember to perform behaviour from seeing it modelled by their parents. However, a long time might elapse before adolescents put into practice the behaviour, which is known as delayed modelling (Bandura, 1986).

When extending the TPB, support was furthermore found for previous smoking behaviour which made a unique contribution to the prediction of adolescents' intentions to smoke as well as to actual smoking behaviour. This is in line with a number of previous studies reporting the importance of past behaviour (Ajzen, 2002b; Conner \& Armitage, 1998; McMillan et al., 2005).

The results of the TPB model and the extended TPB model clearly depict the relative impact of the TPB variables as opposed to the impact of the extension variables. While the TPB model explained $28 \%$ of the variance in smoking behaviour and $14 \%$ in the variance of adolescents' intentions to smoke, the extension variables together added $15 \%$ to the explained variance of smoking behaviour and $13 \%$ to the explained variance of intentions to smoke. This implies that the TPB components explained a large part of smoking behaviour and intentions, although the extension variables made a clear contribution in further explaining smoking behaviour.

Although the present study addressed important methodological limitations of past studies, this study has its own limitations. First, we did not use the expectancy-value model to measure the TPB constructs (Ajzen, 1991). However, the expectancy-value model might not be the best way to describe the relationship between direct and indirect measures of constructs of TPB (Ajzen, 1991; Gagné \& Godin, 2000). By measuring the constructs solely by beliefs, one can avoid scaling problems resulting from multiplying two variables not measured on a ratio scale. Second, longer time frames were used for some of the included TPB components which may have resulted in a lower predictive power of the TPB components. Third, we did not validate self-reported smoking by bio-chemical measures. Self-reports, however, have been found to be reliable and to correspond well with biological indicators under measurement conditions that assure anonymity (Dolcini, Adler, \& Ginsberg, 1996). Although questionnaires could not be completely anonymous due to the need to match participant's friends to their own questionnaires, the ESFA project did optimize measurement conditions by guaranteeing strict confidentiality of adolescent responses (De Vries, et al., 2003). Fourth, direct measures of parental and sibling smoking were not available. Previous research, however, has demonstrated that adolescents are reliable sources for assessing the smoking behaviour of their parents (Harakeh, Engels, De Vries, \& Scholte, 2006). Fifth, although one of the strengths of the present study is looking at the impact of different agents (parents, siblings, and friends), this resulted in assessing the agent specific constructs with only two items. Future research should aim to assess each construct with a larger number of items. Finally, future research should include other known influences such as effects of media exposure to smoking (Sargent, Gibson, \& Heatherton, 2009; Weiss et al., 2006) and test interaction effects such as whether the extension variables discussed could possibly also moderate the effect of PBC on smoking.

This study has several practical implications. First, although our findings were in agreement with the TPB (Ajzen, 1991), descriptive norms significantly improved the prediction of adolescent smoking behaviour and intention to smoke, which suggests a broader conceptualization of subjective norms in the TPB. Our findings furthermore suggest that in the context of adolescent smoking, the TPB might be extended with 
previous smoking behaviour, direct pressure, and smoking-based selection of friends. However, more research is needed to examine whether these results can be replicated in different populations. Second, smoking prevention aimed at reducing smoking behaviour should consider the impact of smoking-based selection of friends. Previous research demonstrated that the structure of peer environments needs more attention within prevention (Cottler et al., 1998; Dishion \& Owen, 2002; Valente, 2006; Valente, Hoffman, Ritt-Olson, Lichtman, \& Johnson, 2003). Programmes creating non-smoking majorities within groups, working with popular peers, or opinion leaders as role models such as the A Stop Smoking in School Trial study (Campbell et al., 2008), or increasing selfawareness regarding imitation and selection processes based on smoking behaviour, may be effective in preventing smoking. Third, smoking prevention aiming at increasing the pressure not to smoke, or teaching to resist pressure to smoke, might reduce adolescent smoking. School-based programmes teaching adolescents to deal with direct pressure have shown modest positive results on smoking behaviour (Crone et al., 2003). This study confirms the importance of the social environment in the process of smoking initiation and highlights that using a social network approach in smoking prevention will likely be beneficial.

\section{Acknowledgements}

This study is funded by NWO (The Netherlands Organization for Scientific Research; 401-01555). The ESFA project is funded by the European Commission (The Tobacco Research an Information Fund; 96/IT/13-B96Soc96201157).

\section{References}

Ajzen, I. (1991). The theory of planned behavior. Organizational Behavior and Human Decision Processes, 50, 179-211. doi:10.1016/0749-5978(91)90020-T

Ajzen, I. (2002a). Constructing a TpB questionnaire: Conceptual and methodological considerations. Retrieved from http://www-unix.oit.umass.edu/ aizen/pdf/tpb.measurement.pdf

Ajzen, I. (2002b). Residual effects of past on later behavior: Habituation and reasoned action perspectives. Personality and Social Psychology Review, 6(2), 107-122. doi:10.1207/S15327957PSPR0602_02

Ajzen, I., \& Fishbein, M. (1980). Understanding attitudes and predicting social behavior. Englewood Cliffs, NJ: Prentice-Hall.

Aloise-Young, P. A., Graham, J. W., \& Hansen, W. B. (1994). Peer influences on smoking initiation during early adolescence: A comparison of group members and group outsiders. Journal of Applied Psychology, 79(2), 281-287. doi:10.1037/0021-9010.79.2.281

Armitage, C. J., \& Conner, M. (2001). Efficacy of the theory of planned behavior: A meta-analytic review. British Journal of Social Psychology, 40, 471-499. doi:10.1348/014466601164939

Avenevoli, S., \& Merikangas, K. R. (2003). Familial influences on adolescent smoking. Addiction, 98(Suppl. 1), 1-20. doi:10.1046/j.1360-0443.98.s1.2.x

Bandura, A. (1977). Social learning theory. Englewood Cliffs, NJ: Prentice-Hall.

Bandura, A. (1986). Social foundations of thought and action: A social cognitive theory. New York: Prentice-Hall.

Bauman, K. E., \& Ennett, S. T. (1996). On the importance of peer influence for adolescent drug use: Commonly neglected considerations. Addiction, 91(2), 185-198. doi:10.1111/j.13600443.1996.tb03175.x

Bauman, K. E., \& Fisher, L. A. (1986). On the measurement of friend behavior in research on friend influence and selection: Findings from longitudinal studies of adolescent smoking and drinking. Journal of Youth and Adolescence, 15(4), 345-353. doi:10.1007/BF02145731 
Bentler, P. M., \& Yuan, K. H. (1999). Structural equation modeling with small samples: Test statistics. Multivariate Behavioral Research, 34, 181-197. doi:10.1207/S15327906Mb340203

Bergen, A. W., \& Caporaso, N. (1999). Cigarette smoking.Journal of the National Cancer Institute, 91(16), 1365-1375. doi:10.1093/jnci/91.16.1365

Bricker, J. B., Anderson, M. R., Rajan, K. B., Sarason, I. G., \& Peterson, A. V., Jr. (2007). The role of schoolmates' smoking and non-smoking in adolescents' smoking transitions: A longitudinal study. Addiction, 102(10), 1665-1675. doi:10.1111/j.1360-0443.2007.01945.x

Bricker, J. B., Peterson, A. V., Jr., Anderson, M. R., Leroux, B. G., Rajan, K. B., \& Sarason, I. G. (2006). Close friends', parents', and older siblings' smoking: Reevaluating their influence on children's smoking. Nicotine and Tobacco Research, 8(2), 217-226. doi:10.1080/14622200600576339

Bricker, J. B., Peterson, A. V., Jr., Leroux, B. G., Anderson, M. R., Rajan, K. B., \& Sarason, I. G. (2006). Prospective prediction of children's smoking transitions: Role of parents' and older siblings' smoking. Addiction, 101, 128-136. doi:10.1111/j.1360-0443.2005.01297.x

Campbell, R., Starkey, F., Holliday, J., Audrey, S., Bloor, M., Parry-Langdon, N., ... Moore, L. (2008). An informal school-based peer-led intervention for smoking prevention in adolescence (ASSIST): A cluster randomised trial. Lancet, 371(10), 1595-1602. doi:10.1016/S01406736(08)60692-3

Chassin, L., Presson, C. C., Rose, J. S., \& Sherman, S. J. (1996). The natural history of cigarette smoking from adolescence to adulthood: Demographic predictors of continuity and change. Health Psychology, 15(6), 478-484. doi:10.1037/0278-6133.15.6.478

Cohen, J. M. (1977). Sources of peer group homogeneity. Sociology of Education, 50, 227-241. doi: $10.2307 / 2112497$

Conner, M., \& Armitage, C. J. (1998). Extending the theory of planned behavior: A review and avenues for further research. Journal of Applied Social Psychology, 28(15), 1429-1464. doi:10.1111/j.1559-1816.1998.tb01685.x

Conrad, K. M., Flay, B. R., \& Hill, D. (1992). Why children start smoking cigarettes: Predictors of onset. British Journal of Addiction, 87, 1711-1724. doi:10.1111/j.1360-0443.1992.tb02684.x

Cottler, S., Compton, W. M., Ben Abdullah, A., Cunningham-Williams, R., Abram, F., Fichtenbaum, C., \& Dotson, W. (1998). Peer delivered interventions reduce HIV risk behaviors among outof-treatment drug abusers. Public Health Reports, 113, 31-41.

Crone, M. R., Reijneveld, S. A., Willemsen, M. C., van Leerdam, F. J. M., Spruijt, R. D., \& Hira Sing, R. A. (2003). Prevention of smoking in adolescents with lower education: A school based intervention study. Journal of Epidemiology and Community Health, 57, 675-680. doi:10.1136/jech.57.9.675

Currie, C., Roberts, C., Morgan, A., Smith, R., Settertobulte, W., Samdal, O., \& Vivian Barnekow, R. (2004). Young people's bealth in context. Health behaviour in school-aged children (HBSC) study: International report from the 2001/2002 survey. Copenhagen: World Health Organization Regional Office.

De Vries, H., Backbier, E., Kok, G., \& Dijkstra, M. (1995). The impact of social influences in the context of attitude, self-efficacy, intention, and previous behavior as predictors of smoking onset. Journal of Applied Social Psychology, 25(3), 237-257. doi:10.1111/j.15591816.1995.tb01593.x

De Vries, H., Dijk, F., Wetzels, J., Mudde, A., Kremers, S., Ariza, C., .. . Candel, M. (2006). The European Smoking Prevention Framework Approach (ESFA): Effects after 24 and 30 months. Health Education Research, 21, 116-132. doi:10.1093/her/cyh048

De Vries, H., Dijkstra, M., \& Kuhlman, P. (1988). Self-efficacy: The third factor besides attitude and subjective norm as a predictor of behavioural intentions. Health Education Research, 3(3), 273-282. doi: 10.1093/her/3.3.273

De Vries, H., Engels, R., Kremers, S., Wetzels, J., \& Mudde, A. (2003). Parents' and friends' smoking status as predictors of smoking onset: Findings from six European countries. Health Education Research, 18(5), 627-636. doi:10.1093/her/cyg032 
De Vries, H., Mudde, A., Leijs, I., Charlton, A., Vartiainen, E., Buijs, G., . . Kremers, S. (2003). The European Smoking Prevention Framework Approach (ESFA): An example of integral prevention. Health Education Research, 18(5), 611-626. doi:10.1093/her/cyg031

Dijkstra, M., Mesters, I., De Vries, H., van Breukelen, G., \& Parcel, G. S. (1999). Effectiveness of a social influence approach and boosters to smoking prevention. Health Education Research, 14(6), 791-802. doi:10.1093/her/14.6.791

Dishion, T. J., \& Owen, L. D. (2002). A longitudinal analysis of friendship and substance use: Bidirectional influence from adolescence to adulthood. Developmental Psychology, 38(4), 480-491. doi:10.1037/0012-1649.38.4.480

Dolcini, M. M., Adler, N. E., \& Ginsberg, D. (1996). Factors influencing agreement between self-reports and biological measures of smoking among adolescents. Journal of Research on Adolescence, 6(4), 515-542.

Engels, R. C. M. E., Knibbe, R. A., Drop, M. J., \& de Haan, Y. T. (1997). Homogeneity of cigarette smoking within peer groups: Influence or selection? Health Education and Behavior, 24(6), 801-811.

Ennett, S. T., \& Bauman, K. E. (1994). The contribution of influence and selection to adolescent peer group homogeneity: The case of adolescent cigarette smoking. Journal of Personality and Social Psychology, 67(4), 653-663. doi:10.1037/0022-3514.67.4.653

Evans, R. I. (1976). Smoking in children: Developing a social psychological strategy of deterrence. Preventive Medicine, 5, 122-127. doi:10.1016/0091-7435(76)90015-3

Ezzati, M., \& Lopez, A. D. (2003). Estimates of global mortality attributable to smoking in 2000. Lancet, 362(13), 847-852. doi:10.1016/S0140-6736(03)14338-3

Fisher, L. A., \& Bauman, K. E. (1988). Influence and selection in the friend-adolescent relationship: Findings from studies of adolescent smoking and drinking. Journal of Applied Social Psychology, 18(4), 289-314. doi:10.1111/j.1559-1816.1988.tb00018.x

Gagné, C., \& Godin, G. (2000). The theory of planned behavior: Some measurement issues concerning belief-based variables. Journal of Applied Social Psychology, 30(10), 2173-2193. doi:10.1111/j.1559-1816.2000.tb02431.x

Godin, G., Valois, P., Lepage, L., \& Desharnais, R. (1992). Predictors of smoking behaviour: An application of Ajzen's theory of planned behaviour. British Journal of Addiction, 87, 13351343. doi:10.1111/j.1360-0443.1992.tb02742.x

Grube, J. W., Morgan, M., \& McGree, S. T. (1986). Attitudes and normative beliefs as predictors of smoking intentions and behaviours: A test of three models. British Journal of Addiction, 25, 81-93.

Guo, Q., Johnson, C. A., Unger, J. B., Lee, L., Xie, B., Chou, C.-P., . . Pentz, M. (2007). Utility of the theory of reasoned action and theory of planned behavior for predicting Chinese adolescent smoking. Addictive Behaviors, 32, 1066-1081. doi:10.1016/j.addbeh.2006.07.015

Harakeh, Z., Engels, R., De Vries, H., \& Scholte, R. H. J. (2006). Correspondence between proxy and self-reports on smoking in a full family study. Drug and Alcohol Dependence, 84(1), 40-47. doi:10.1016/j.drugalcdep.2005.11.026

Harakeh, Z., Engels, R., Vermulst, A. A., De Vries, H., \& Scholte, R. H. J. (2007). The influence of best friends and siblings on adolescent smoking: A longitudinal study. Psychology and Health, 22(3), 269-289. doi:10.1080/14768320600843218

Hill, A. J., Boudreau, F., Amyot, E., Déry, D., \& Godin, G. (1997). Predicting the stages of smoking acquisition according to the theory of planned behavior. Journal of Adolescent Health, 21, 107-115. doi:10.1016/S1054-139X(97)00039-6

Hoving, C., Reubsaet, A., \& De Vries, H. (2007). Predictors of smoking stage transitions for adolescent boys and girls. Preventive Medicine, 44, 485-489. doi:10.1016/j.ypmed.2007.02.011

Kobus, K. (2003). Peers and adolescent smoking. Addiction, 98(Suppl. 1), 37-55. doi:10.1046/ j.1360-0443.98.s1.4.x

Kremers, S., Mudde, A., \& De Vries, H. (2001a). Kicking the initiation: Do adolescent ex-smokers differ from other groups within the initiation continuum? Preventive Medicine, 33(5), 392401. doi:10.1006/pmed.2001.0904 
Kremers, S., Mudde, A., \& De Vries, H. (2001b). Subtypes within the precontemplation stage of adolescent smoking acquisition. Addictive Behaviors, 26(2), 237-251. doi:10.1016/S03064603(00)00104-0

Lawrance, L. (1989). Validation of a self-efficacy scale to predict adolescent smoking. Health Education Research, 4(3), 351-360. doi:10.1093/her/4.3.351

McAlister, A. L., Perry, C., \& Maccoby, N. (1979). Adolescent smoking: Onset and prevention. Pediatrics for the Clinician, 63(4), 650-658.

McCallister, L., \& Fisher, C. S. (1978). A procedure for surveying personal networks. Sociological Methods and Research, 7(2), 131-148. doi:10.1177/004912417800700202

McMillan, B., Higgins, A. R., \& Conner, M. (2005). Using an extended theory of planned behaviour to understand smoking amongst schoolchildren. Addiction Research and Theory, 13(3), 293306. doi:10.1080/16066350500053679

Mercken, L., Candel, M., Willems, P., \& De Vries, H. (2007). Distentangling social selection and social influence effects on adolescent smoking: The importance of reciprocity in friendships. Addiction, 102, 1483-1492. doi:10.1111/j.1360-0443.2007.01905.x

Mercken, L., Candel, M., Willems, P., \& De Vries, H. (2009). Social influence and selection effects in the context of smoking behavior: Changes during early and mid adolescence. Health Psychology, 28, 73-82. doi:10.1037/a0012791

Mercken, L., Snijders, T. A. B., Steglich, C., \& De Vries, H. (2009). Dynamics of adolescent friendship networks and smoking behavior: Social network analyses in six European countries. Social Science and Medicine, 69, 1506-1514. doi:10.1016/j.socscimed.2009.08.003

Mercken, L., Snijders, T. A. B., Steglich, C. E. G., Vartiainen, E., \& de Vries, H. (2010). Dynamics of adolescent friendship networks and smoking behavior. Social Networks, 32, 72-81. doi:10.1016/j.socnet.2009.02.005

Mermelstein, R. (1999). Ethnicity, gender and risk factors for smoking initiation: An overview. Nicotine and Tobacco Research, 1, S39-S43. doi:10.1080/14622299050011791

Muthén, L. K., \& Muthén, B. O. (2004). Mplus user's guide (3rd ed.). Los Angeles, CA: Author.

Office for National Statistics (1997). Living in Britain: Preliminary results from the 1996 General Household Survey. London: The Stationary Office.

Parker, J. G., \& Asher, S. R. (1993). Friendship and friendship quality in middle childhood: Links with peer group acceptance and feelings of loneliness and social dissatisfaction. Developmental Psychology, 29(4), 611-621. doi:10.1037/0012-1649.29.4.611

Rivis, A., \& Sheeran, P. (2003). Descriptive norms as an additional predictor in the theory of planned behaviour: A meta-analysis. Current Psychology, 22(3), 218-233. doi:10.1007/s12144003-1018-2

Sargent, J. D., Gibson, J., \& Heatherton, T. F. (2009). Comparing the effects of entertainment media on tobacco marketing on youth smoking. Tobacco Control, 18, 47-53. doi:10.1136/tc.2008.026153

Sheeran, P., \& Orbell, S. (1999). Augmenting the theory of planned behavior: Roles of anticipated regret and descriptive norms. Journal of Applied Social Psychology, 23, 2107-2142. doi:10.1111/j.1559-1816.1999.tb02298.x

Simons-Morton, B. G., \& Chen, R. S. (2006). Over time relationships between early adolescent and peer substance use. Addictive Behaviors, 31(7), 1211-1223. doi:10.1016/j.addbeh.2005.09.006

Smith, B. N., Bean, M. K., Mitchell, K. S., Speizer, I. S., \& Fries, E. A. (2007). Psychosocial factors associated with non-smoking adolescents' intentions to smoke. Health Education Research, 22(2), 238-247. doi:10.1093/her/cyl072

Urberg, K. A., Luo, Q., Pilgrim, C., \& Degirmencioglu, S. M. (2003). A two-stage model of peer influence in adolescent substance use: Individual and relationship-specific differences in susceptibility to influence. Addictive Behaviors, 28, 1243-1256. doi:10.1016/S03064603(02)00256-3

Valente, T. W. (2006). Opinion leader interventions in social networks. British Medical Journal, 333(7578), 1082-1083. doi:10.1136/bmj.39042.435984.43 
Valente, T. W., Hoffman, B. R., Ritt-Olson, A., Lichtman, K., \& Johnson, A. (2003). Effects of a social-network method for group assignment strategies on peer-led tobacco prevention programs in schools. American Journal of Public Health, 93(11), 1837-1843. doi:10.2105/AJPH.93.11.1837

Warren, C. W., Jones, N. R., Eriksen, M. P., \& Asma, S. (2006). Patterns of global tobacco use in young people and implications for future chronic disease burden in adults. Lancet, 367(9512), 749-753. doi:10.1016/S0140-6736(06)68192-0

Weiss, J. W., Cen, S., Schuster, D. V., Unger, J. B., Johnson, C. A., Mouttapa, M., . . Cruz, T. B. (2006). Longitudinal effects of pro-tobacco and anti-tobacco messages on adolescent smoking susceptibility. Nicotine and Tobacco Research, 8, 455-465. doi:10.1080/14622200600670454

West, P., Sweeting, H., \& Ecob, R. (1999). Family and friends' influences on the uptake of regular smoking from mid-adolescence to early adulthood. Addiction, 94(9), 1397-1412. doi:10.1046/j.1360-0443.1999.949139711.x

Received 4 May 2010; revised version received 23 August 2010 